\title{
Review of Cost Effectiveness of Organisation Structure of Benue Cement Company Plc Gboko towards Achieving Its Marketing Objective: An Empirical Analysis
}

\author{
Richard Jimin Agema, Hembadoon Diaka, Bukola Rebecca Oyeleye \\ Department of Business Management, Faculty of Management Science, Benue State University, Makurdi, Nigeria
}

\begin{abstract}
The main objective of this study is to present an empirical review of whether Benue Cement Company PLC Gboko adopted a cost-effective organization structure towards achieving its marketing objective. The study adopts mix research methods of Survey, historical, descriptive, analytical and empirical. The Company's Population consisted of 326 top and middle level Managers and 910 for lower-level Managers. The Sample population of 44 employees were drawn for the study covering the Four levels of management. This consisted of 3 Top managers, 20 middle level managers, 9 First level Supervisors, 12 Clerical staff. The data collection method adopted for the study is through questionnaire, literature reviews, company documents, and personal observations. Data analysis technique adopted for the study is simple percentages, frequency tables, and pie chart. Results of findings from the study revealed that, the Company did not adopt a cost-effective organization structure to achieve the Company's marketing objective. The company adopted a long chain of command and communication as depicted by the company's organizational structure as presented in appendixes I and II in variance with empirical recommendations evidence. This kind of structure is contrary to what Schewe (1987) recommended that: "for organization to survive, it should have a shorter chain of communication and command". The Company's restructuring effort of 1994 and 2001 did not make significant changes in the cost reduction efforts to achieve the company's strategic business objectives, as stated in the company's mission statement as..., "to achieve effective and efficient resources utilization" with the aim to make profit. The study recommends that to be cost effective to achieve its marketing objective, the company should have an organisation structure with a shorter Chain of command and communication and work towards reducing wastes in production activities.
\end{abstract}

Key words: Cost Effective, Benue Cement Company PLC, Organisation Structure, Marketing Objective.

\section{INTRODUCTION}

$\mathrm{T}$ he constant and uncontrollable changes that occur in the contemporary business environment according to Toledo (2009) demand permanent adaptations and adjustments in productive and administrative products and processes, and those who do not attempt to adequately know the new environmental conditions will face difficulties to grow and survive. Companies are exposed to drastic changes in managerial and cultural paradigms, and many are disoriented and pathless in the face of the situations prevalent in the external environment. In this technical-cultural revolution scenario, strategic planning and marketing planning stand out as guiding instruments for the improvement of company competitiveness, push forth the growth of the organization and articulate changes in organizational structures. In this direction Schewe (2007) stressed that organizational structure and design are critically important to market place success and pointed out succinctly that: "No purpose is served by instilling and nurturing the market philosophy if the structure of the organisation makes it impossible for the people to deliver on their promises and that the traditional structure of larger organisations, the functional pyramid, is designed for internal efficiency but is relatively rigid in the face of a constantly changing market place." Therefore, he recommended that, if an Organisation is to survive in today's fast changing environment, it must make itself more responsive to its customers. The question then is how responsive was the management of Benue Cement Company PLC in the management of the company's operations?

\section{Statement of Problem}

Benue Cement Company PLC Gboko organization structure as presented in appendixes I and II depicts a long chain of command and communication within the organization structure of the company. The organogram shows that the company had large number of top, middle and lower level Managers that was not cost effective to manage and achieve its marketing objective in terms of competitiveness and profitability. Some of the major problems that militated against optimal performance of cement companies in Nigeria with particular reference to Benue cement Company Plc over the decades was attributed to many factors. They include: low-capacity utilization, low production output, - which leads to scarcity of the company's product. In addition, other factors include, higher prices, high distribution cost, weak liquidity which makes it difficult to source for spare parts and other vital production inputs. Furthermore, erratic power supply from National Electric Power Authority, higher prices of petroleum products and expensive interest rate on Bank 
Loans. (BCC PLC Annual Reports and Accounts. 1995:6; 1999:6; 2000:6).

\section{Objective of the study}

The main objective of this Paper is to present an empirical review of whether Benue Cement Company PLC Gboko adopted a cost effective Organisation structure to achieve the company's marketing objective.

\section{Research Questions:}

Does Benue Cement Company PLC adopt an organization structure that is cost effective to achieve its marketing objective?

\section{LITERATURE REVIEW}

In structuring an effective organisational structure Pearce and Robinson (2002) posited that the starting point in examining effective organisation structure is in contrasting characteristics, it offers a historical or evolutionary perspective on organisational attributes associated with successful strategy execution today and just a few years ago." They reasoned that successful organisation once required an internal focus, structured interaction, self-sufficiency, a topdown approach. They stated categorically that "today and tomorrow, organisation structure should reflects an external focus, flexible, interaction, interdependency, and bottom-up approach, just to mention a few charateristics associated with strategy execution and success. They postulated that "three fundamental trends are driving decisions about effective organisational structure i.e. globalisation, the internet and speed of decision making". As the topic suggests, let's use the above empirical background as a mirror to re-examine the organization structure of Benue Cement Company Plc.

Operational effectiveness (OE) according to Porter (2011) meant "performing those activities better - that is, faster or with fewer inputs, and defects - than rivals. It refers to a number of practices that allow a company to better utilise its inputs by for example reducing defects in products or developing better products faster." In contrast, Porter stated that differences in operating effectiveness among companies are pervasive, and noted that some companies are able to get more out of their inputs than others, because they eliminate wasted efforts, employ more advanced technology, motivate employees better or have greater insight into managing particular activities or set of activities. He posited that such activities in operational effectiveness are important sources of differences in profitability among competitors because they directly affect relative cost positions and levels of differentiation.

The organizational structure as cited in Agbim, Oriarewo and Zever, (2014) is a framework of roles, responsibilities, authority and communication relationships that are deliberately designed to accomplish an organization's tasks and achieve its objectives. The organizational structure is also called the organizational chart or organogram Ottih,, (2008).
The organisational structure of Benue Cement Company Plc by its design and arrangement could be described as a functional structure as its arrangement suggests in the foregoing paragraphs. The structure underwent a number of developmental changes to meet it desired objectives. However, this study provides only two accessible Organograms that reviews were made as presented in the appendices I and II on pages 17 and 18 . By the restructuring arrangement, top of the structure is the shareholders of the company who are the owners of the company. Directly below was the Chairman, Board of Directors and twelve (12) appointed members of the Board of Directors of the Company. This suggests a tall structure made up of management team.

In accordance with the provisions of Section 334 and 335 of the Companies and Allied Matters Decree of 1990 members of the Board of Directors are responsible for the preparation of financial statements which give a true and fair view of the state of affairs of the company as at the end of the financial year and its results for a particular period and to comply with the Companies and Allied Matters Decree 1990. These responsibilities include:

i. Adequate internal control procedures and instituted to safeguard assets and prevent and detect fraud and other irregularities.

ii. Ensure that proper accounting records are maintained.

iii. Applicable accounting standards are followed.

iv. Suitable accounting policies are used and consistently applied.

v. The financial statements are prepared on the going concern biases unless it is in a private concern to presume that the company will continue in business. BCC Plc (1995:8) Annual Report \& Accounts

Under the Board of Directors are the Managing Director and Chief Executive of the company. Below the Managing Director and Chief Executive were the Finance, Audit, Management Services Division, Commercial Division, Technical Division and Legal Service Department, headed by the General Manager. The Technical except Commercial Division were headed by an Assistant General Manager who was on the same level of responsibility and authority with the General Managers of Finance and Personnel as well as Technical - they report directly to the Managing Director and Chief Executive.

Similarly, the Mangers or officers for Chief Internal Audit, Lagos Liaison Office Corporate Planning and Data Processing, Public Relation, Procurement and Abuja Liaison Office managers also reported direct to the Managing Director and Chief Executive of the company as provided by the Organogram of the company. The Finance and Personnel Division was sub-divided into Finance and Personnel subdivision and Training Departments. Training and Stores Department were headed by a Manager, while Financial 
Accounts was headed by a Chief Financial Accountant. The Departments responsible for Financial Accounting, budgeting and cost control in the company respectively. Personnel subdivision was headed by an Assistant General Manager. He reports directly to the General Manager Finance and Personnel.

The Departments under personnel division are Administration, headed by a Manager. Units under Administration are Transport, Security, Radio Room operations, and Reception Hall. All these units were managed by their respective officers and staff. Another Department under Personnel Division was the Personnel and Admin Department, headed by a Manager. He reports directly to the AGM Personnel and Admin. The units under these Departments were employee relation/recruitment and Personnel records, welfare, travel, catering, factory clinic and safety.

The Department was responsible for staff recruitment, placement, discipline, promotion, provision of medical services, staff welfare and general motivational schemes for staff of the company. On the other hand, the Administrative Department was in charge of housing, insurance, office equipment and staff welfare as well etc. The Commercial division was made up of Depots and Distribution, Sales and Marketing and Deport Department headed by a Manager, who reports to the AGM Commercial. The Distribution Department was responsible for the distribution and dispatch of cement to the company's depots in the state and other parts of the country. The Marketing and Sales Department was responsible for the sales, appointment of distributors and dispatches of cement and other associated operations such as invoicing. Depot Department was responsible for the sale of the company's product direct to customers from the designated depots within and outside the state in the country.

There were other Departments like Internal Audit, Lagos Liaison Office, Corporate Planning and Data Processing, Public Relations, Procurement and Abuja Office were not grouped under any specific arrangement in the structure, but had specific functions and responsibilities. Unlike other Managers, the Managers of these Departments, the Chief Internal Auditor, and the Legal Services Manager/Company Secretary and Legal Adviser were directly responsible to the Managing Director and Chief Executive of the Company. A General Manager made up of production, engineering services and maintenance sub-division heads the Technical Department. Assistant General Managers each heads these sub-divisions respectively. The Production Department was made up of the Packaging Plant Department, Production Department, Quarry and Quality Control Department each headed by a Manager.

The Packaging Plant was responsible for packaging the finished product into cement bags for the distribution and sells. Quarry Department was responsible for mining of raw materials and repair of heavy earth-moving mobile plants. Quality Control Department was responsible for Quality
Control of the company's Lion Brand Portland cement to ensure that it meets the Nigerian Standard Organisation requirements. Engineering Services sub-division was made up of Project and Design Department headed by a manager. Heavy Mobile Plant Department and Estate Maintenance Department each headed by a Manager. The Civil Electrical Engineering Department, Power House Maintenance Department and Instrumentation Department each was headed by a Manager. The Engineering Service and Maintenance subdivision were responsible for installation and maintenance of all electrical systems both in the plant and Housing Estate and Installation and Maintenance and overhauling of all mechanical systems in the plant including Housing Estates and repair of vehicles. The office of Company Secretary/Legal Adviser was headed by a Legal Services Manager, who reports directly to the Managing Director and Chief Executive. The Department was responsible for providing legal advisory services to the Chief Executive Officer of the Company and was responsible for all legal related matters of the Company. (Corporate Planning and Data Processing Department, 1994, and 2001)

\section{METHODOLOGY}

The research methodology adopted for the study is a mix method of survey, historical, descriptive, analytical, and empirical methods.

\section{Research Method}

The research methods adapted for this study is survey, historical, descriptive, analytical and empirical methods.

\section{Data Collection methods}

The data collection method adapted for this study is through primary sources: observation, Questionnaire, and secondary sources of data through Literature Reviews.

\section{Description of Population}

The company, Benue Cement Company PLC had Staff strength of 1,236 employees. This Population consisted of 326 top and middle level Managers and 910 for lowe level Managers. A Sample population of 44 employees were drawn for the study covering the Four levels of management. This consisted of 3 Top managers, 20 middle level managers, 9 First level Supervisors, and 12 Clerical Staff. This sample was taken from the seventeen (17) Departments under Managing Director and Chief Executive. The seventeen departments were under General Manager Audit (1); General Manager Commercial (2); General Manager Management Services (2); General manager Technical Services (9); Company Secretary/ Legal Adviser (1); and General Manager Finance (2). Therefore, an average two (2) copies of the questionnaire were administered per Department and one copy each to each the eight (8) offices of the General Managers and two copies to the Managing Director's Office this brings the total sample to 44 participants for the study covering all the Departments of the company. 


\section{Sample and Sampling procedure}

A cluster sample frame of 44 employees were selected for the study. The participants for the study were administered with copies of the questionnaire in their offices. The copies of the questionnaire were distributed during break period. They were to complete the questions in the questionnaire within 30 minutes after its administration. In addition, the sample was made up of 3 top level, 20 middle level managers, 9 first level supervisors, 7 clerical staff with years of service ranged between 5 to 34 and 4 blank copies of the questionnaire. They had $7,8,10,11$ and 4 , years of service respectively. The sample also consisted of 29 males, 10 females and 5 blank copies of the questionnaire returned. They consisted of 32 married, 8 single and 4 blank copies of the questionnaire returned. Their level of education consisted of 13 HND/OND, 16 First Degree, 3 Master's Degree; 6 PGDM and 6 uncompleted copies of the questionnaire. Their ages ranged between 20 to 60 years.

\section{Data analysis Techniques}

The data analysis techniques designed for this study is the application of descriptive statistics with the use of tables, frequencies, percentages, and Pie-chart.

\section{DISCUSSION OF FINDINGS}

To provide solutions the above research question, the researchers relied on the responses from the respondents to research question on: whether the company adopted the right organization structure that is cost effective to achieve the company's strategic Marketing objective. In this segment, the researchers have classified the data presentation into two segments. In the first segment, attempt is made to classify participants' responses according to demographic variables into: age, level of education, sex, marital status, years of service and job status. In the second segment, the researchers presented the research question for the study. The questions in the questionnaire were framed bearing in mind the research objectives. The data is presented in tabular form, in frequencies, percentages and Pie chart. To achieve a coherent and logical presentation, literature review survey findings which provides theoretical foundations was applied to the research question for the study. The data presented is analyzed based on respondent's opinions drawn from results of the field survey conducted with support from empirical evidence and conclusions are drawn with relevant citations from appropriate primary and secondary sources of research.

\section{Age Distribution of Respondents}

The data generated from field survey conducted as presented in table 1 below on age distribution of respondents' shows that there were 11 respondents representing $25 \%$ of the sample for those who are between the ages of $20-35$. This segment of the company's staff strength could be regarded as the most active age segment because of its youthfulness.
Table 1: Age Distribution

\begin{tabular}{|c|c|c|c|}
\hline S/No & Response Category & Frequency & $\begin{array}{c}\text { Percentage } \\
(\%)\end{array}$ \\
\hline 1 & $20-35$ & 11 & $25 \%$ \\
\hline 2 & $36-50$ & 25 & $57 \%$ \\
\hline 3 & $51-60$ & 04 & $09 \%$ \\
\hline 4 & Blank Response & 04 & $09 \%$ \\
\hline & Total & 44 & $100 \%$ \\
\hline
\end{tabular}

Source: Field Survey Data 2002.

In addition, there are 25 respondents constituting $57 \%$ of the sample for those employees between the age of 36 - 50 years old. This segment of the company's staff strength could be regarded as a fairly active segment of the employees. There were 04 respondents representing $09 \%$ of the sample for those within the age of $51-60$ years old. This segment constitutes employees who could be regarded as less active segment of the staff population, because they are approaching retirement age.

\section{Level of Education Distribution}

Table 2 below shows that no primary and secondary school level category of employees participated in the responses. There were 13 respondents at post-secondary school level representing $30 \%$ of the sample. Also, there were 16 respondents representing $36 \%$ of the sample for Graduate level employees. In addition, there are 03 respondents representing $06 \%$ and 06 respondents representing $14 \%$ of the sample were employees with Postgraduate diploma qualifications.

Table 2: Level of Education of Respondents

\begin{tabular}{|c|c|c|c|}
\hline S/No & Response Category & Frequency & $\begin{array}{c}\text { Percentage } \\
(\%)\end{array}$ \\
\hline 1 & HND/OND & 13 & $30 \%$ \\
\hline 2 & First Degree & 16 & $36 \%$ \\
\hline 3 & Masters Degree & 03 & $06 \%$ \\
\hline 4 & PGDM & 06 & $14 \%$ \\
\hline 5 & Blank Response & 06 & $14 \%$ \\
\hline & Total & 44 & $100 \%$ \\
\hline
\end{tabular}

Source: Field Survey Data 2002.

The respondents' level of education has direct relationship with their ability to understand the questions designed in the questionnaire for this research investigations. Thus, their ability to understand the questions in the questionnaire has direct implications on the quality of their response and the results of the survey conducted.

\section{Sex Distribution of Respondents}

Table 3 below shows that 29 respondents representing $66 \%$ of the sample are males, while 10 respondents representing $23 \%$ 
of the sample are females. There were 05 blank responses representing $11 \%$ of the sample. Thus, the above data shows that there are 19 men more men than women in the company, who participated in the survey conducted.

Table 3: Sex Distribution

\begin{tabular}{|c|c|c|c|}
\hline S/No & Response Category & Frequency & Percentage (\%) \\
\hline 1 & Male & 29 & $66 \%$ \\
\hline 2 & Female & 10 & $23 \%$ \\
\hline 3 & Blank Response & 05 & $11 \%$ \\
\hline & Total & 44 & $100 \%$ \\
\hline
\end{tabular}

Source: Field Survey Data 2002.

In Nigerian context it has become traditional to find more men than women on the job in our public and private sector. However, increased level of education for females could change the trend comparatively, men could be said to be more stable on the job than women especially those that are married. Thus, married women are known to have more family responsibilities than men, because of nursing the children and other domestic responsibilities. This usually affect their stability on the job and can negatively affect the operational performance and their productivity as a result of frequent absenteeism to attend to one family problem or the other, at the detriment of their assigned responsibilities on the job.

\section{Respondents Marital Status Distribution}

Processed data result for this category of respondents as presented in Table 4 below shows that 32 respondents representing $73 \%$ of the sample are married, while only 08 respondents representing $16 \%$ are single, there is no widow or divorced respondents. There were only 04 respondents representing 09\% as blank responses which cannot be discussed further due to non-response.

Table 4: Marital Status Distribution

\begin{tabular}{|c|c|c|c|}
\hline S/No & Response Category & Frequency & $\begin{array}{c}\text { Percentage } \\
(\%)\end{array}$ \\
\hline 1 & Married & 32 & $73 \%$ \\
\hline 2 & Single & 08 & $18 \%$ \\
\hline 3 & Widow & 00 & $00 \%$ \\
\hline 4 & Divorced & 00 & $00 \%$ \\
\hline 5 & Blank Response & 04 & $09 \%$ \\
\hline & Total & 44 & $100 \%$ \\
\hline
\end{tabular}

Source: Field Survey Data 2002.

The married segment of the respondents is regarded as very responsible segments of the company's employees. They are considered to be more likely to take their job serious. The reasons attributed to this, is because married employees are usually more inclined to comply with rules and regulations of their organisation to ensure their job stability and security. Thus, they are usually more careful in the discharge of their assigned job by avoiding sharp practices that may affect their job stability.

\section{Respondents' Years of Service Distribution}

Table 5 below indicates that 07 respondents representing 16\% of the sample are those who have served the company between $1-5$ years. There are 08 respondents representing $18 \%$ of the sample for those who have served the company between $6-10$ years.

Table 5: Years of Service Distribution

\begin{tabular}{|c|c|c|c|}
\hline S/No & Response Category & Frequency & $\begin{array}{c}\text { Percentage } \\
(\%)\end{array}$ \\
\hline 1 & $1-5$ years & 07 & $16 \%$ \\
\hline 2 & $6-10$ years & 08 & $18 \%$ \\
\hline 3 & $11-15$ years & 10 & $23 \%$ \\
\hline 4 & $16-20$ years & 11 & $25 \%$ \\
\hline 5 & $21-34$ years & 04 & $09 \%$ \\
\hline 6 & Blank Response & 04 & $09 \%$ \\
\hline & Total & 44 & $100 \%$ \\
\hline
\end{tabular}

Source: Field Survey Data 2002.

In addition, those who have served between $11-15$ years are 10 representing $23 \%$ of the sample. There are only 04 respondents representing $09 \%$ of the sample for those that have serve for between $21-35$ years. There were 04 respondents representing 09\% as blank response, which cannot be discussed further because of non-response. The implication of the above data presented is that: this is a valuable segment of the sample that can be used as a yardstick for measuring the validity of information drawn from this category of respondents. Thus, the period of five years and above in service in an organisation is significant to acquire adequate skills and experience on the job. This segment of the sample is therefore relevant for providing useful information on the company's operations in terms of its success, problems, and prospects. Consequently, the success and failure of the company therefore depends to a large extent on the quality of its employees.

\section{Respondents' Job Status Distribution}

This is another important segment of the category of respondents. Table 6 below shows that 03 respondents representing $07 \%$ are within the top management category and 20 respondents representing $46 \%$ are within the middle management category. The first two categories of respondents are within policy making and implementation in the organizational hierarchy.

Table 6: Job Status Distribution

\begin{tabular}{|c|c|c|c|}
\hline S/No & Response Category & Frequency & Percentage (\%) \\
\hline 1 & Top Management & 03 & $07 \%$ \\
\hline 2 & Middle Management & 20 & $46 \%$ \\
\hline 3 & First Level Supervisor & 09 & $20 \%$ \\
\hline
\end{tabular}




\begin{tabular}{|c|c|c|c|}
\hline 4 & Clerical Staff & 07 & $16 \%$ \\
\hline 5 & Blank Response & 05 & $11 \%$ \\
\hline & & & \\
\hline & Total & 44 & $100 \%$ \\
\hline
\end{tabular}

Source: Field Survey Data 2002.

Thus, the opinions drawn from this category of respondents for this study are considered highly valuable as a yardstick for measuring the company's performance over the years. Their ranking in terms of job status has direct and indirect implications on the opinions they hold. The decision-making power and ability to influence management decision on policy issues such as staff welfare and the company's operational policies and strategies is of significance.

\section{Analysis of results of findings}

Result of processed data from the field survey conducted as presented in Table 7. and Fig.1. of the Pie Chart below, shows that 29 respondents, representing $65 \%$ of the sample opinioned that BCC PLC did not adopt a cost effective

Table 7: Does BCC PLC adopt a cost effective organization structure to achieve its marketing objective?

\begin{tabular}{|c|c|c|}
\hline Responses & Frequency & Percentage \\
\hline Yes & 13 & $30 \%$ \\
\hline No & 29 & $65 \%$ \\
\hline Blank spaces & 2 & $5 \%$ \\
\hline Total & 44 & 100 \\
\hline
\end{tabular}

Fig. 1. A pie chart showing participants responses to the research question.

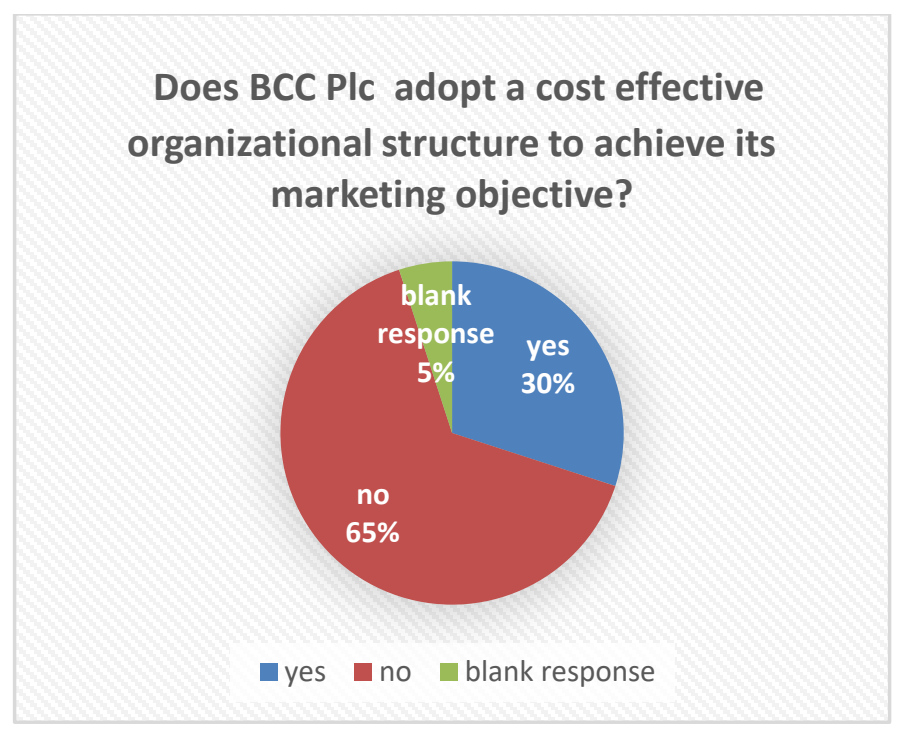

Source: Field Survey Data 2002.

Organization structure to achieve the company's strategic marketing objective. The reasons behind this, the researchers observed, can be linked to the long chain of communication and command adopted by the company as presented in the company's organization structure on appendixes 1 and 11 on pages 17 and 18. This kind of structure is also contrary to what Schewe (1987) that: "for organization to survive, it should have a shorter chain of communication and command."

The case study of BCC Plc is therefore in variance with empirical evidence recommendation (i) below and as you can see appendixes I and II of the company's organization structure, as many workers were employed in staff or noncustomer-related functions. For further empirical analysis to examine effectiveness of the company's organizational structure, in a similar direction, Schewe (ibid) says: "Before a company can put its marketing strategies into operation, it must establish an organizational structure. That is a set of relationships among individuals with different responsibilities and the way a company organizes its marketing activities depends on the emphasis placed on marketing in the company, which in turn depends to a large extent on, whether it is production, sales or marketing oriented." He stressed that organizational structure and design are critically important to market place success and pointed out succinctly that: "No purpose is served by instilling and nurturing the market philosophy, if the structure of the organization makes it impossible for the people to deliver on their promises and that the traditional structure of larger organisations, the functional pyramid, is designed for internal efficiency, but is relatively rigid in the face of a constantly changing market place."

Therefore, Schewe recommended that, if an Organization is to survive in today's fast changing environment, it must make itself more responsive to its customers. Typically, to achieve this goal he posited that, this will mean:

i. Shorter chain of communication and commands;

ii. Fewer people are employed in staff or other noncustomer related functions;

iii. An overall structure that reflects the different needs of the market place rather than technical specialization of employees.

Consequently, this means a further review of the long chain of communication and command structure in BCC Plc to be shorter, and cost effective i.e., the number of management staff are too many as depicted by the company's 1994 and 2001 revised editions of the organisation structure as presented in appendixes I and II on pages 17 and 18 respectively.

It is observed that, such a structure is expensive in terms of human capital cost to the company at the detriment of the investors profit and growth for the company, (See appendixes I and II). Thus, results of the field survey conducted through oral interview with the personnel/Admin and the Public Relations Manager(s) of the company on how many times the company restructured, appendixes I of 1994 and II of 2001 revealed that, over the years the management of the company has restructured the company twice to make its human capital operations' cost effective and result oriented to achieve the company's strategic business objective. 
But, unfortunately, investigations through the company's published sources such as its Annual Report and Account for five years i.e. 2001, 2000, 1999, 1998.and 1997, in the conduct of this study revealed on the contrary that, the restructuring efforts did not make significant changes in the cost reduction efforts by management to achieve the company's set objectives, as stated in the company's mission statement such as..., "to achieve "effective and efficient resources utilization" in an attempt to make profit." To be precise, one of such previous restructuring of the company was that of November 2001 as presented in appendix II on the company's organisation structure. Under the new arrangement, the numbers of Managers were reduced from twenty-five to seventeen and Assistant Managers from six to three; but the top management staff were however increased, with the number of General Managers from two to five with their associated cost on salaries and other emoluments.

In spite of the restructuring of the company, personal observations and secondary sources suggests that, the problems persisted, thereby reducing the level of effective utilization of opportunities by the company for optimal profit. This could be attributed to several factors such as: there were large numbers of managerial staff and very expensive to care for at the detriment of investors' profit and growth of the company. It is obvious from the foregoing that, the company's performance on restructuring and as it affects the success of its marketing operations can be said as also stated by Thompson (1993) to be inadequate and badly directed i.e., not able to market its product effectively to achieve adequate sales over the years for achievement of the company's overall marketing objectives is regarded as one of the indicators for a company underperformance.

With this development, it was obvious that, the company's performance on restructuring and as it affects the success of its marketing operation in terms of profit can be concluded as stated by Thompson (1993) to be inadequate and badly directed i.e., not able to market its product effectively and efficient to achieve adequate sales over the years for achievement of the company's overall business objectives, is regarded as one of the indicators for a company's failure. From the substantiations, it is clear that, no concerted efforts were made to satisfy a wide spectrum of cement users. i. e. and customers. This led to the company's takeover by one of her competitors, Dangote Cement Plc. In year 2000 the Federal Government sold its stake in BCC to Dangote industries Limited. The transaction was officially completed in 2004 and Dangote Industries Limited took full control of the Benue Cement Company PLC in May 2004 as a subsidiary of its Csement Plants in Nigeria.

\section{CONCLUSIONS}

Research findings from empirical evidence, observations, respondents' responses, and literature reviews revealed that, BCC PLC did not adopt a cost-effective organization structure to achieve the company's strategic marketing objective. The company adopted a tall organisational structure that was not cost effective, but also ineffective in meeting customers' demand for the company's product in the market due to scarcity of the company's product. There were large numbers of managerial staff and very expensive to care for at the detriment of investors' profit and growth of the company. Therefore, in spite of the restructuring of the company, personal observations and secondary sources suggests that, the problems persisted, thereby reducing the level of effective utilization of opportunities by the company for optimal profit. Moreover, inadequate financing to support the company's operations was observed to be the major operational constraint that affected the company's competitiveness in the cement market in Nigeria. This negatively affected the company's achievements of its strategic marketing objectives both in the short and long run periods of the company's operations.

\section{RECOMMENDATIONS}

The study recommends that, to cost effective, the management of the company should adopt an organizational structural with a shorter Chain of command and communication at all levels of the company's operations. In addition, to survive in today's fast changing business environment, the company must make itself more responsive to its customers, typically, this will mean, eliminate wasted effort, employ more advanced technology, motivate employees better, have greater insight into managing particular activities, or set of activities. The company should also reduce defects in its product i.e., the "Lion Brand Portland Cement" and develop better product features faster to be more competitive in the market. The researchers also recommend that the company can be cost effective by leasing rather than outright purchase of equipment, discontinuing low-margin-customers, and extending the life span of machinery. Fewer employees should be employed in staff or other non- customer related functions; and an overall structure that reflects the different needs of the market place rather than technical specialization of employees.

\section{REFERENCES}

[1] Agbim, K.C; Oriarewo, G. O. and Zever, T. A. (2014) Contribution of Organisation structure, Leadership and Relationship styles and Innovation Process towards Organisational Innovativeness. International Journal of Economics, Commerce and Management.Vol.11(12). p8.

[2] Annual Reports and Accounts of BCC Plc. (2000, 1999, 1998, 1997, 1996, 1995). Jos: Trinity Graphic limited.

[3] Companies and Allied Matters Decree 1990.

[4] Benue Cement Company Plc. (2001) Corporate Planning and Data Processing Department.

[5] Ottih, L.O. (2008). Organization theory: Structure, Design and Process. Port Harcourt: Amex Publications.

[6] Schewe, C. D. (1987). Marketing Principles and Strategies, First Edition. New York: Random House.

[7] Thompson \& Strickland (1996) Strategic Management Concepts and Cases; Ninth Edition. Boston: Irwin McGraw-Hill

[8] Thompson, J.L. (1993). Strategic Management Awareness \& Change Second Edition. London: Chapman \& Hall.

[9] Toledo, L. A. (2009) Organizational Structures within the Scope of Strategic Marketing Planning: A Discursive Study. Rev. Adm. UFSM, Santa Maria, vol. 2, (2). Pp. 180-196. 
[10] Pearce, J. A. and Robinson, R. B. (2002). Strategic management Formulation, Implementation and Control, Eight Edition. Boston: McGraw-Hill Irwin. Pp.277-278.
Porter, M. E. (2011). On Strategy: What is Strategy. USA:

Harvard Business School Publishing Corporation. Pp.2-3. 
APPENDIX I (1994 Review)

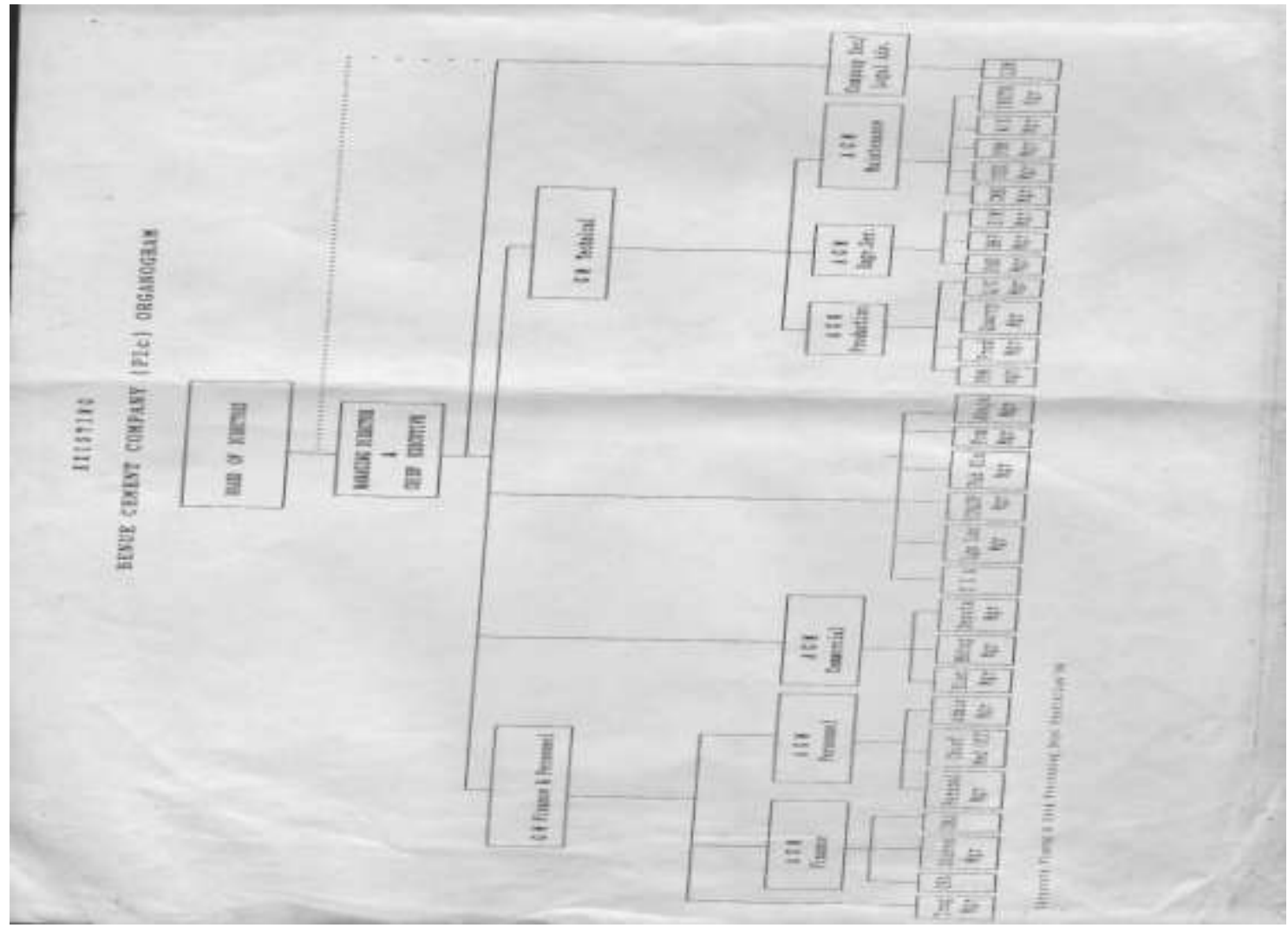

APPENDIX II (2001 Review)

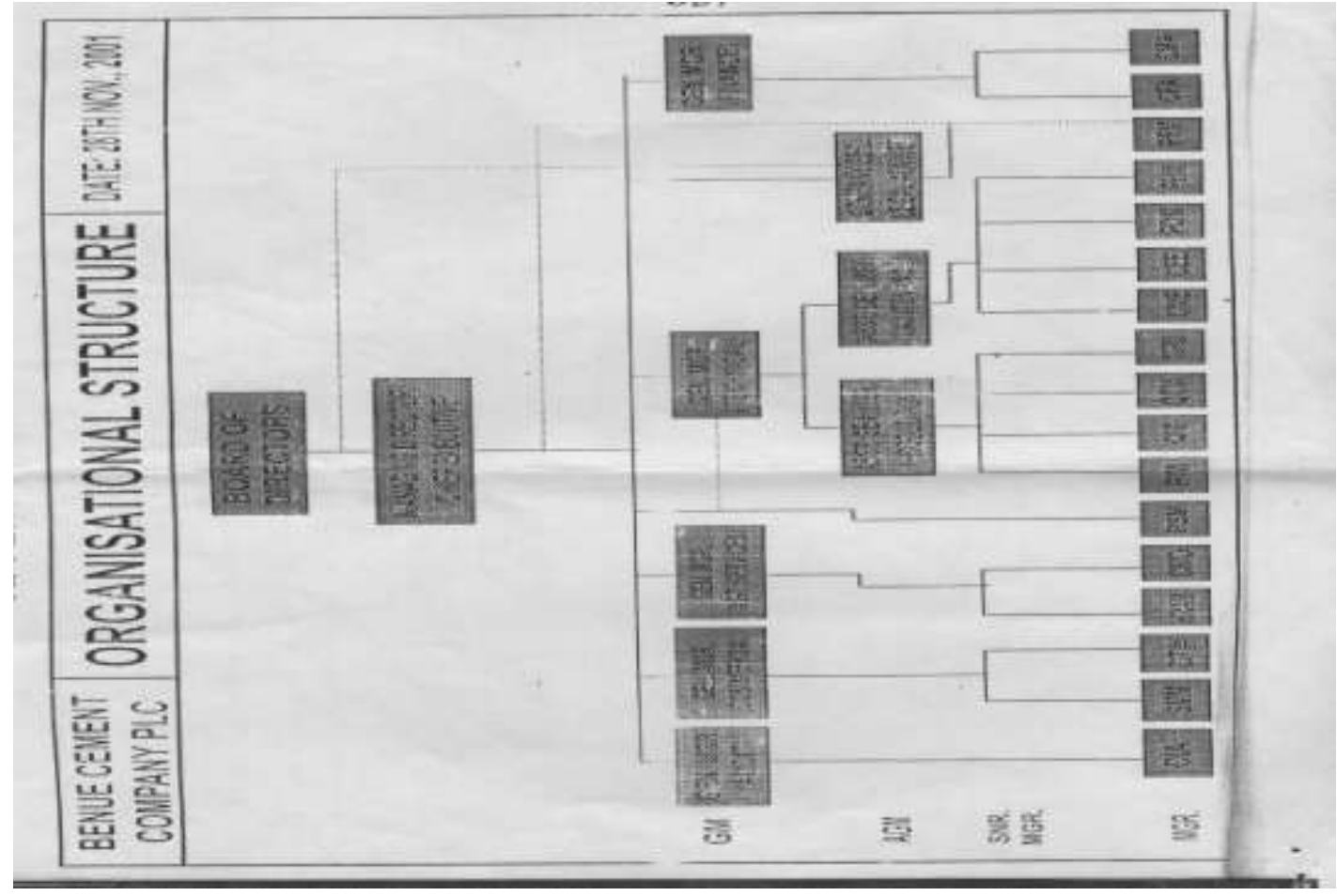

